\title{
ENERGY EFFICIENCY OF A PUBLIC BUILDING RENOVATION AND RECONSTRUCTION USING BASE MODEL PASSIVE HOUSE AND BIM TECHNOLOGY
}

\author{
Romas RASIULIS ${ }^{\mathrm{a}}$, Leonas USTINOVICHIUS ${ }^{\mathrm{a}, \mathrm{b}}$, Darius MIGILINSKAS ${ }^{\mathrm{a}}$, \\ Jovita CEPURNAITEa ${ }^{a}$, Arvydas VIRBICKAS ${ }^{a}$ \\ ${ }^{a}$ Vilnius Gediminas Technical University, Sauletekio al. 11, LT-10223 Vilnius, Lithuania \\ ${ }^{b}$ Bialystok University of Technology, ul. Wiejska 45a, 15-351 Bialystok, Poland
}

Received 2015 July 04; accepted 2015 October 26

\begin{abstract}
Modern constructions, either private houses or public buildings, nowadays must be built meeting all the requirements of the European Union [EU] standards and must be highly energy efficient. Still, there are a lot of old inefficient buildings with high energy costs that require renovation. These buildings can be renovated applying a passive house model that helps to minimize buildings' heating and cooling energy expenses. Moreover, the decisions made in the stages of early design and preconstruction are essential for the sustainability in a building facility. It is possible to perform various analyses with Building Information Modeling (BIM) in order to have an optimized sustainable building design. BIM system can be used to evaluate and control the costs (e.g. renovation, efficiency) as well as to monitor the conditions during the life-cycle of the building.
\end{abstract}

Keywords: passive house, building, information, modeling, TOPSIS, SAW, COPRAS, SyMAD-3.

\section{Introduction}

Environmentally, economically and socially sustainable villages, towns and cities are the most urgent challenge of the $21^{\text {st }}$ century (Jarrar, Al-Zoabi 2008).

Buildings have direct environmental impact, ranging from the use of raw materials for their construction and renovation to the consumption of natural resources and the emission of harmful substances (Balaras et al. 2005). Design of buildings should take long-term environmental and economic benefits into consideration (Wang et al. 2010).

Economical, social and environmental balance is promoted in sustainable construction practice implementing construction projects. Sustainable construction practice refers to various methods in the process of implementing construction projects that involve less harm to the environment. Energy performance of a building is an estimated energy content expressed as a building energy performance class required when using the building for its intended purpose (STR 2.01.09: 2012).

A Passive House is a building, for which thermal comfort (LST EN ISO 7730:2006) can be achieved solely by heating or cooling of the fresh air mass, which is required to achieve sufficient indoor air quality conditions - without the additional air recirculation (Bayir et al. 2013).

Energy efficiency has been attracting more society attention, because the expenses of the energy consumption for heating take a big part of the revenue. These costs can be reduced several ways: by lowering energy prices, increasing energy and constructing (renovating) buildings with less energy consumption (Volvačiovas et al. 2012).

Public building is a building intended to public needs taking into account provisions for STR 
1.01.09:2003 that covers hotels, administrative buildings, trade buildings, service buildings, catering buildings, transport buildings, culture buildings, education buildings and religious buildings (STR 2:02:02:2004). Most of the public indoor facilities climatic conditions do not meet the requirements of the Lithuanian hygiene standard, i.e. they do not fulfill the thermal comfort parameters, so they must be renovated in accordance to the hygiene standard of Lithuania (HN 42: 2009).

Under certain conditions, efficient energy demand can be achieved by selecting the building design changes. Technological advances and innovations of materials and construction techniques of the industry allow development of new solutions to be used in each element of the building (San-José Lombera, Cuadrado Rojo 2014).

The BIM technology (the future technology of the constructions (Harris 2013)) would help to solve the high costs, terms of construction process, life cycle and design model reconstructing public buildings of chosen alternative construction issues. It is a new industry term referring to parametric $3 \mathrm{D}$ visualization technology and processes in the AEC industry (Taylor, Bernstein 2009; Popov et al. 2010). BIM is one of the most promising recent developments in AEC industry (Azhar 2011). BIM includes more of life cycle phases, integrates program controls and standardizes information management so that meanings are clear and consistent (Talapov 2011). It is an additional model for project's engineering information database, storing all the architectural designs with geometric information and the corresponding technical information of all work (Ding et al. 2012).

The ability to import buildings' data from BIM reduces time and uncertainty in building energy modeling process. BIM technology requires significantly more labor resources than traditional design model. The workforce needs breakthrough for sections', elevations', specific parts' (heating, ventilation and electricity) preparation (Wong, Fan 2012).

The 4D technology use allows the construction planner to produce the more rigorous schedules (Heesom, Mahdjoubi 2004; Migilinskas et al. 2013).

\section{Materials and problems}

All the existing problems should be taken into consideration while renovating public and other buildings.
Problems are individual in each case and unique to a particular building, however, the summarized data of the studies show often encountered ones:

1. Indoor temperature $\left({ }^{\circ} \mathrm{C}\right)$ is too high or too low.

2. Great indoor temperature $\left({ }^{\circ} \mathrm{C}\right)$ contrast at 0.10 and at $1.10 \mathrm{~m}$ above the floor.

3. Ground temperature $\left({ }^{\circ} \mathrm{C}\right)$ is too low.

4. Humidity (\%) is too low or too high.

5. Indoor airflow $(\mathrm{m} / \mathrm{s})$ is too high.

6. Carbon dioxide $\left(\mathrm{CO}_{2}\right)$ concentration (\%) is too high.

7. High heating, hot water production and power supply (kWh) expenses.

8. High building physical depreciation (\%): constructions, windows, doors, internal engineering systems.

9. Poor building external appearance.

These indicators show public buildings characteristics.

So as to find the solutions of the problems, a passive house principle model (Fig. 1) is applied to address the public building renovation issues.

The Vaidotai railway station of a $2168.00 \mathrm{~m}^{2}$ building general area, built in 1980, is selected for a study. This is the five-story building with a local gas boiler located in the basement. The building outer walls

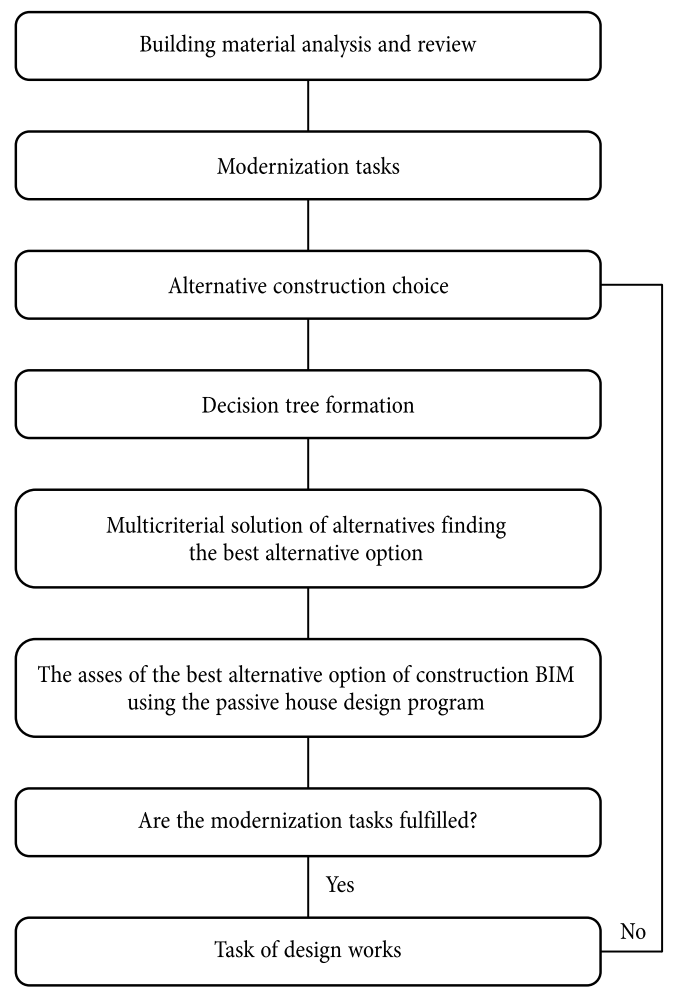

Fig. 1. Passive house model 
are built of $510 \mathrm{~mm}$ thick silicate brick masonry and $400 \mathrm{~mm}$ thick reinforced concrete blocks plinth. Walls are not plastered from the outside but are plastered and painted from the inside. The roof is superposed, covered with the membrane roofing. The ventilation chimneys' tinning is worn out.

The decoration of the walls and ceilings are worn out. The facade plane has visible cracks of 1-1.4 mm.

The degree of the building isolation and non isolated spots of the building must be determined before starting the isolation works. The obtained results will show the necessity of the insulation and its degree.

The physical depreciation of $25 \%$ of the building was set during the examination using the $\mathrm{BCH} 53$ 86 (p) method. The air temperature of the premises does not meet the requirements of Lithuanian hygiene norms, because the indoor temperature should range from 18 up to $22^{\circ} \mathrm{C}$ during the cold season. Thermal conductivity measurements of the barrier zones showed that the heat transfer coefficient of the Vaidotai st. EC checkpoint external walls and roofs is too small and does not meet Lithuanian Construction Technical Regulation links.

The estimated building reconstruction areas:

1. Heat insulating layer and a deposited coating are recommended to install. During the repair works the parapet tinning must be restored. The tinning works of the worn out curbs must be performed, the masonry walls must be restored and caps replaced. It is recommended for the ceilings that are under the reinforced concrete roof flooring to be restored using the finishing tools - such as filler together with the glass fiber grids for the seams.

2. Examination of the building showed that the structural condition of the outer walls of the building is in satisfactory condition. It is proposed to insulate the walls of a building and to install the outside cladding layer.

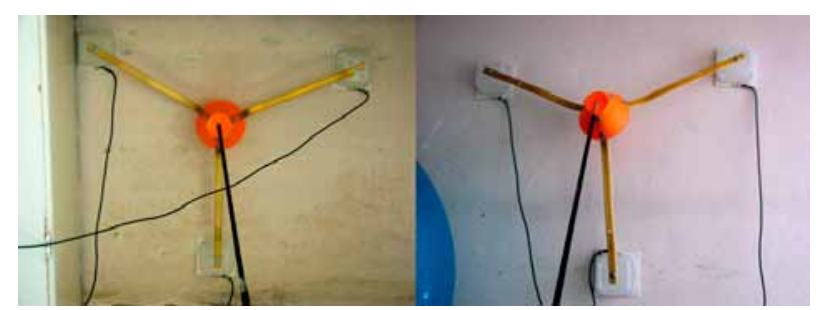

Fig. 2. The heat flow laboratory equipment measuring the external partition
3. The building examination showed that the plinth structure is in satisfactory condition. It is proposed to insulate the plinth construction and to install the outside cladding layer.

4. It is recommended to replace the windows and the doors.

All the problems listed above are caused by low thermal resistance of the floor, walls, roof, windows, doors, including improper ventilation and uneconomic solutions in the building, and the other reasons.

\section{The heat transfer coefficient indicator setting}

All the audit parameters of the partition structures are set according to the actual measurements and using the following methods.

The parameters of the heat transfer coefficient, thermal conductivity of the partition structures, surface temperature, indoor and outdoor air temperature, and other microclimate parameters are measured using the measuring devices of the Ahlborn MESSund Regelungstechnic GmbH (Germany) manufacturer (Fig. 2) that consist of:

- ALMEMO 2890-9 data logger with the measurement data memory;

- FQA018CSI (ALMEMO ${ }^{\circ}$ ) model for the heat flow measurements of the thermo plates' couples;

- FHA646-E1 (ALMEMO ${ }^{\circ}$ ) model sensors and probes for the temperature and relative humidity measurement;

- FHA646 (ALMEMO ${ }^{\circ}$ ) model of the air temperature probe;

- FVA605-TA10 (ALMEMO ${ }^{\circledR}$ ) thermo manometer model;

- FY A600-CO 2 H (ALMEMO ${ }^{\circ}$ ) CO2 model for the gas measuring probe.

Thermal transmission coefficient of the external partitions identification methodology is: heat transfer coefficient $U$ of the external partitions is defined by measuring the heat flow $q$; the indoor air temperature $\theta_{i}$ and the outside air temperature $\theta_{e}$ using formula:

$$
U=q /\left(\theta_{i}-\theta_{e}\right), \mathrm{W} / \mathrm{m}^{2} \mathrm{~K},
$$

where: $q$ - is the average of the measured heat flows through the external walls; W/MC; $\theta_{i}$ - the average indoor air temperature; ${ }^{\circ} \mathrm{C} ; \theta_{e}$ - the average outside air temperature; ${ }^{\circ} \mathrm{C}$. 
Special laboratory devices with autonomous management software were originated for these investigations. For the accuracy of the study the heat flow was measured at 3 different spots of the same external partition at the same time. Heat flow and temperature were measured every 30 minutes around the clock. The ALME$\mathrm{MO}^{\circledR}$ 2890-9 data memory results of measurements were computer scanned and the graphs drawn (Fig. 3), and the average heat transfer coefficient values calculated.

The Vaidotai st. EC post partition thermal transmission coefficient test results show that the $510 \mathrm{~mm}$ thick outer wall heat transfer coefficient $U_{s}=$ $1.30 \mathrm{~W} / \mathrm{m}^{2} \mathrm{~K},\left(R=0.77 \mathrm{~m}^{2} \cdot \mathrm{K} / \mathrm{W}\right)$. This factor was set
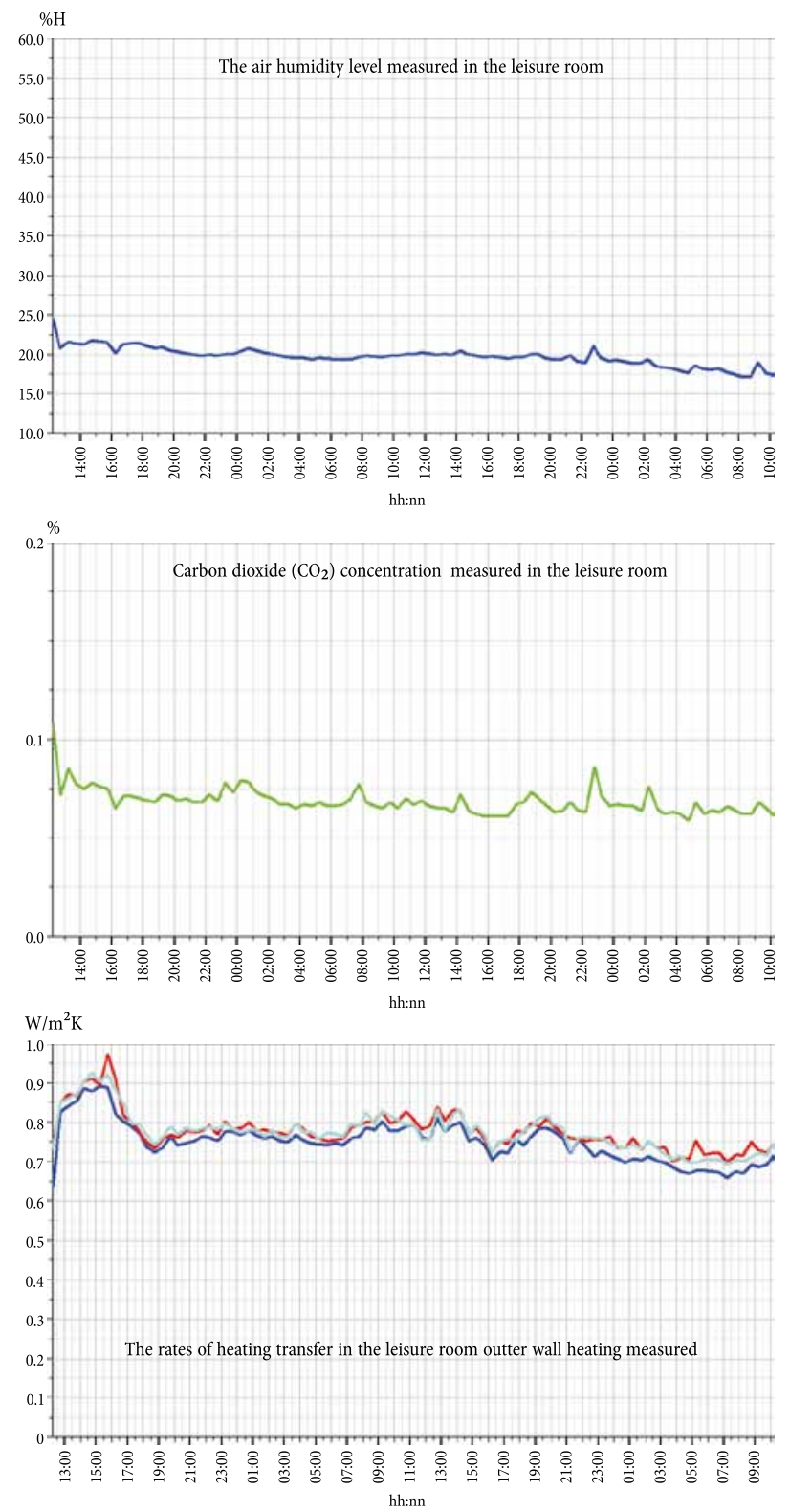

Fig. 3. Relative humidity, $\mathrm{CO}_{2}$ concentration, external wall surface temperature measurements of the north-west edge of the building room No.1-28 room measurements. This wall is on the high northwest side and it is mostly damaged. It follows, that the heat transfer coefficient of the Vaidotai st. EC external walls and roof is too small and does not meet the technical requirements of construction of regulations of Lithuania. It is recommended for the external walls and roof to be additionally insulate.

\section{The estimate of experimental research}

Certain techniques must be applied and basic decision model (as it is shown in Fig. 4) must be created in order for the Vaidotai st. EC modernization benefit issue to be rationally formulated and solved and the best decisions made.

Foremost, the model identifies the options of insulation of plinths, walls and roof, and the combination variants.

The best modernization alternatives are selected out of all the chosen alternatives before resolving the Vaidotai st. EC checkpoint modernization task.

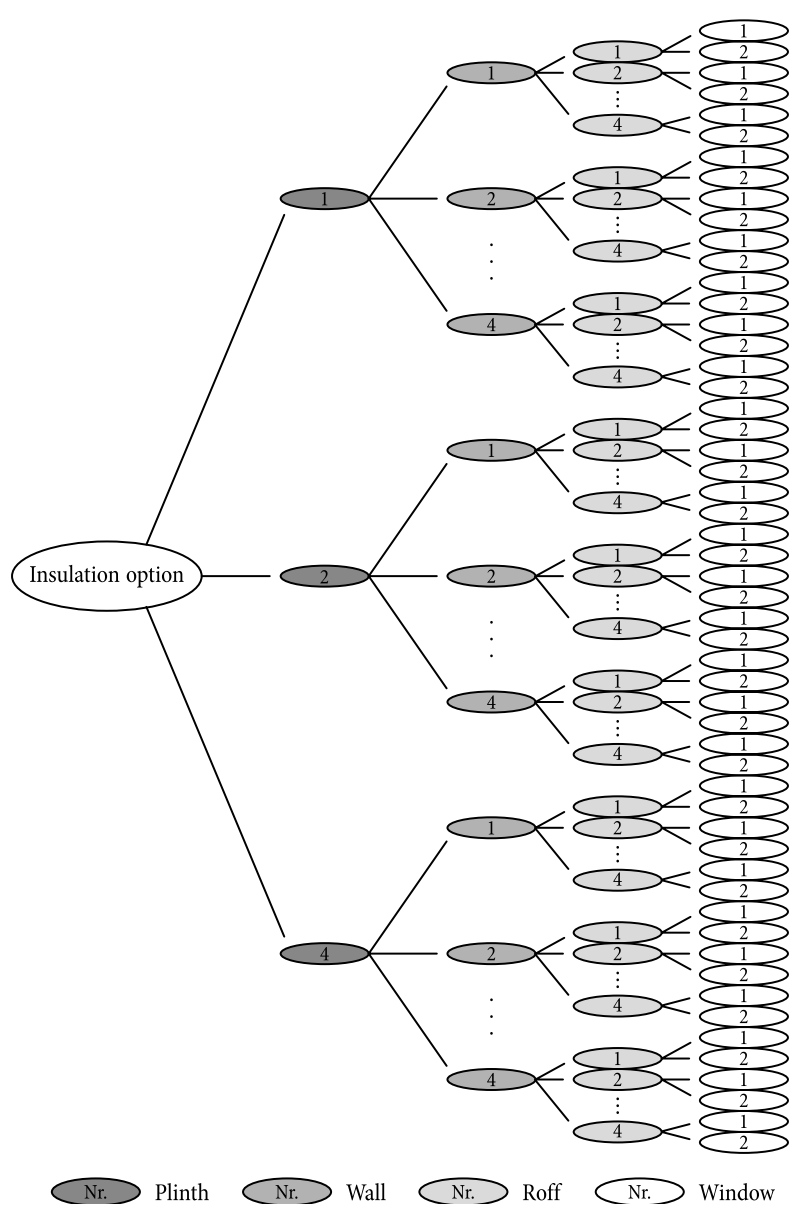

Fig. 4. Decision tree 
Therefore, the following building parts are being analyzed: the plinth part, external walls, and roof. Required thermal conductivity $U$ of the construction:

$$
\begin{array}{ll}
\text { Walls } & U=0.10-0.15 \mathrm{~W} /\left(\mathrm{m}^{2} \mathrm{~K}\right) \text {; } \\
\text { Roof } & U=0.09-0.12 \mathrm{~W} /\left(\mathrm{m}^{2} \mathrm{~K}\right) \text {; }
\end{array}
$$

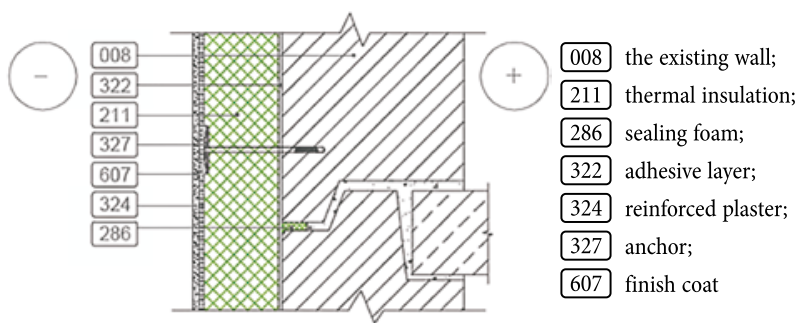

Fig. 5. Walls alternative details

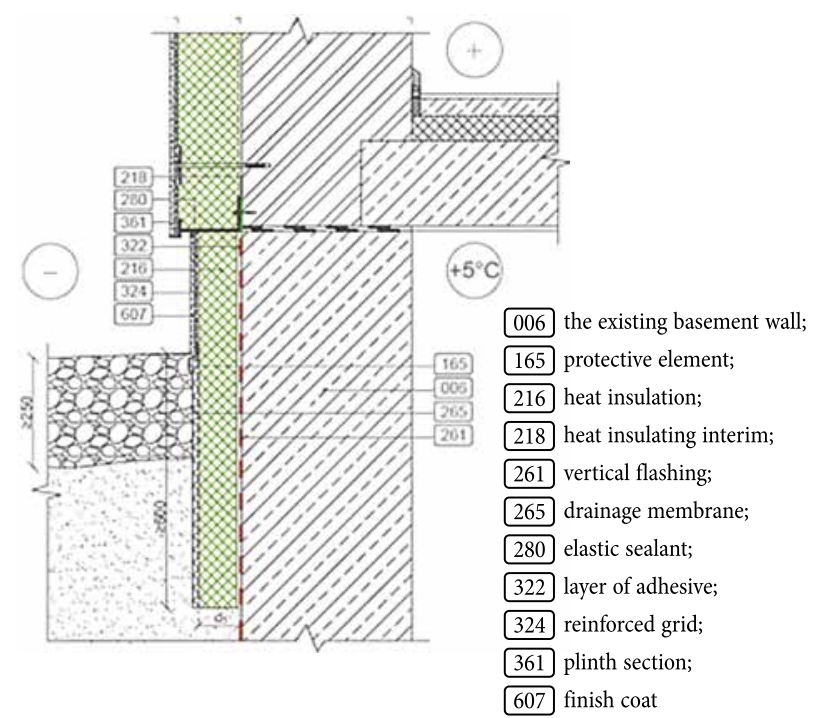

Fig. 6. Plinth alternative details

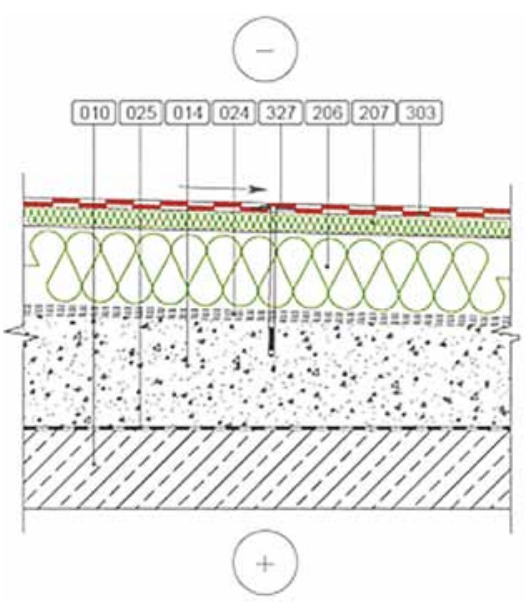

010 the existing reinforced concrete;

206 lower mineral wool layer;

014 the existing aerated concrete slab; 207 the upper layer of mineral wool;

024 the existing hydro isolation;

303 rolled-out covering;

025 the existing steam insulation;

327 anchor

Fig. 7. Roof alternative details $\begin{array}{ll}\text { Plinth } & U=0.12-0.18 \mathrm{~W} /\left(\mathrm{m}^{2} \mathrm{~K}\right) \text {; } \\ \text { Windows } & U=0.70 \mathrm{~W} /\left(\mathrm{m}^{2} \mathrm{~K}\right) .\end{array}$

Optional selected heating type is being selected for each building part alternative by identifying the construction type materials, specifying their technical data (shown in Figs 5, 6, 7).

The fallowing indicators are selected during the Vaidotai st. EC post examination of plinth, exterior walls, and roof:

- heat transfer factor $U, \mathrm{~W} / \mathrm{m}^{2} \mathrm{~K}$;

- modernization costs, Eur;

- projected lifetime, years;

- scores of possibility to carry out construction work, regardless of seasonality;

- annual savings MWh / $\mathrm{m}^{2}$ / year;

- simple payback, years;

- operating care complexity, scores.

The description and the method determining the heat transfer coefficient are given in Chapter 3 .

Lifetime indicator exercises description. This rate is determined by the projected warranty period of used instruments. This forecasted period depends on maintenance and use of the building for its intended purpose. This is a maximized quantitative indicator.

The feasibility indicator's description. This is a qualitative indicator measured on a scale from 1 to 6. Present construction work complexity depends on the season. The points of the capacity to carry out the construction work, regardless of the season, are:

- 1-2 points - work that cannot be carried out at the certain season of the year;

- 3-4 points - when the seasonality can be taken partially;

- 5-6 points - fully seasonal depending.

Annual savings rate. Some energy savings are expected after modernization when the thermal characteristics of the building improve. Heat loss through the partials, heating costs, and amount of required heat is reduced because of the outer envelope insulation. So the annual energy savings $\mathrm{MWh} / \mathrm{m}^{2}$ are set. This indicator is quantitative and maximized.

Simple payback time rate. Energy-savings, modernization measures and required investment ratings are presented. Comprehensive economic and technical efficiency analyses are carried out for each measure. Simple and real payback and savings of energy costs are calculated in order to evaluate the energy saving measures for economic efficiency. 
Simple payback time (PAL - quantitative indicator and it is minimized) of the planned investment for energy saving measures is determined by the following formula:

$$
P A L-I / S \text {, }
$$

where: $P A L$ - years; $I$ - planned investments, EUR; $S$ planned annual savings of installing energy conservation measures, Eur/year.

Operating care rate of complexity determination. This is a qualitative indicator that is measured on a scale from 1 to 6 . Each alternative is assessed by the complexity of operation maintenance level as each modernization option has some complexity issues of the maintenance. Operating care difficulty scoring is classified as:

- 1-2 points - difficult to maintain;

- 3-4 points - less difficul to maintain;

- 5-6 points - easy to perform maintenance.
Purpose change indicator. This is a qualitative indicator measured on a scale from 1 to 6 . Alternatives are evaluated in terms of how easy it is to replace the purpose of the building. Purpose change options points:

- 1-2 points - complicated purpose change;

- 3-4 points - less complicated purpose change;

- 5-6 points - simple purpose change.

The initial data tables are compiled for each of the building components after selecting the Vaidotai st. EC modernization indicators and alternatives (see Tables 1-3).

\section{Materiality determination of indicators}

Each purpose is expressed by indicators. Indicators show our objectives and are subject to change depending on the objectives pursued. Only the most efficient

Table 1. Plinth modernization versions

\begin{tabular}{|c|c|c|c|c|c|c|c|}
\hline \multirow[b]{2}{*}{ Plinth modernization alternatives } & \multicolumn{7}{|c|}{ Plinth modernization indicators } \\
\hline & 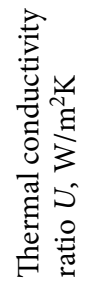 & 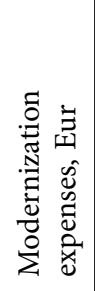 & 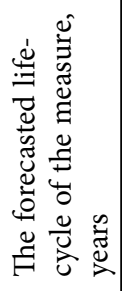 & 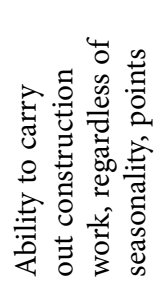 & 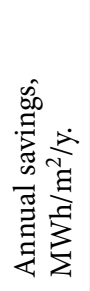 & 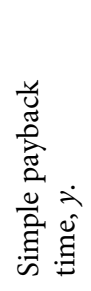 & 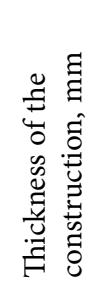 \\
\hline $\begin{array}{l}\text { Plinth } 1 \\
\text { Plinth }\left(95.3 \mathrm{~m}^{\prime}\right) 800 \mathrm{~mm} \text { depths and } 130 \mathrm{~mm} \text { thickness } \\
\text { polystyrene foam EPS } 100 \text { insulation } \\
\text { Finishing tiles } \\
\text { Newly installed paving around the building }\end{array}$ & 0.18 & 31611 & 30 & 2 & 3 & 12 & 600 \\
\hline $\begin{array}{l}\text { Plinth } 2 \\
\text { Plinth }\left(95.3 \mathrm{~m}^{\prime}\right) 800 \mathrm{~mm} \text { depths and } 160 \mathrm{~mm} \text { thickness } \\
\text { polystyrene foam } \\
\text { EPS } 100 \text { insulation } \\
\text { The foam is hydro insulating plastered } \\
\text { Newly installed paving around the building }\end{array}$ & 0.16 & 32485 & 25 & 2 & 3.66 & 12 & 630 \\
\hline $\begin{array}{l}\text { Plinth } 3 \\
\text { Plinth }\left(95.3 \mathrm{~m}^{\prime}\right) 800 \mathrm{~mm} \text { depths and } 200 \mathrm{~mm} \text { thickness } \\
\text { polystyrene foam } \\
\text { EPS } 100 \text { insulation with a } 600 \mathrm{~mm} \text { injection into the ground } \\
\text { The above ground foam covered with a decorative plate and } \\
\text { the underground foam covered with a papillae membrane } \\
\text { Newly installed paving around the building }\end{array}$ & 0.14 & 33650 & 27 & 6 & 3.78 & 15 & 670 \\
\hline $\begin{array}{l}\text { Plinth } 4 \\
\text { Plinth }\left(95.3 \mathrm{~m}^{\prime}\right) 600 \mathrm{~mm} \text { depths and } 250 \mathrm{~mm} \text { thickness } \\
\text { extruded polystyrene foam EPS } 80 \text { insulation } \\
\text { The above ground foam covered with a thin plaster and the } \\
\text { underground foam covered with a papillae membrane } \\
\text { Newly installed paving around the building }\end{array}$ & 0.12 & 35106 & 25 & 2 & 3.89 & 14 & 720 \\
\hline Minimized/maximized & $\min$ & $\min$ & $\max$ & $\max$ & $\max$ & $\min$ & $\max$ \\
\hline Significance, $q$ & 0.121 & 0.254 & 0.151 & 0.0461 & 0.173 & 0.175 & 0.0804 \\
\hline
\end{tabular}


Table 2. Walls modernization versions

\begin{tabular}{|c|c|c|c|c|c|c|c|}
\hline \multirow[b]{2}{*}{ Walls modernization alternatives } & \multicolumn{7}{|c|}{ Walls modernization indicators } \\
\hline & 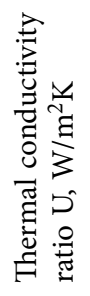 & 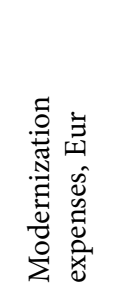 & 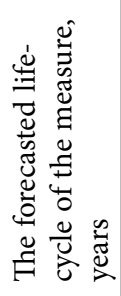 & 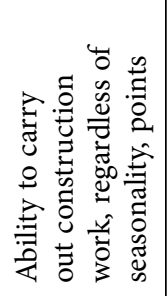 & 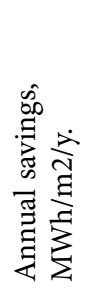 & 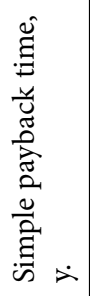 & 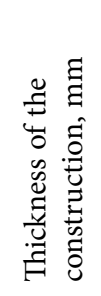 \\
\hline $\begin{array}{l}\text { Wall } 1 \\
\text { Wall }\left(1655 \mathrm{~m}^{2}\right) 180 \mathrm{~mm} \text { thickness polystyrene foam EPS } 70 \mathrm{~F} \\
\text { insulation and thin plastering }\end{array}$ & 0.15 & 361508 & 25 & 3 & 58.8 & 12 & 690 \\
\hline $\begin{array}{l}\text { Wall } 2 \\
\text { Wall }\left(1655 \mathrm{~m}^{2}\right) 200 \mathrm{~mm} \text { thickness polystyrene foam EPS 70F } \\
\text { (NEOPORAS)insulation and thin plastering }\end{array}$ & 0.14 & 369985 & 26 & 4 & 59.75 & 12 & 710 \\
\hline $\begin{array}{l}\text { Wall } 3 \\
\text { Wall }\left(1655 \mathrm{~m}^{2}\right) 240 \mathrm{~mm} \text { stone wool insulation, } \\
\text { The windward stone wool of } 30 \mathrm{~mm} \\
20 \mathrm{~mm} \text { ventilation gap } \\
10 \mathrm{~mm} \text { font panel }\end{array}$ & 0.11 & 424520 & 27 & 6 & 62.59 & 15 & 780 \\
\hline $\begin{array}{l}\text { Wall } 4 \\
\text { Wall }\left(1655 \mathrm{~m}^{2}\right) 310 \mathrm{~mm} \text { stone wool insulation } \\
\text { The stone wool fastened using glue and pins } \\
\text { The reinforcing mesh is used } \\
\text { Thin plaster layer is plastered }\end{array}$ & 0.10 & 489439 & 25 & 3 & 63.54 & 13 & 820 \\
\hline Minimized/maximized & $\min$ & $\min$ & $\max$ & $\max$ & $\max$ & $\min$ & $\max$ \\
\hline Significance, $q$ & 0.140 & 0.245 & 0.136 & 0.0468 & 0.162 & 0.172 & 0.0976 \\
\hline
\end{tabular}

Table 3. Roof modernization versions

\begin{tabular}{|c|c|c|c|c|c|c|c|}
\hline \multirow[b]{2}{*}{ Roof modernization alternatives } & \multicolumn{7}{|c|}{ Roof modernization indicators } \\
\hline & 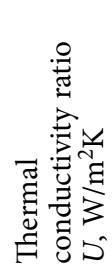 & 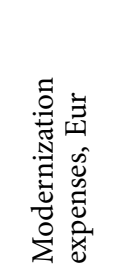 & 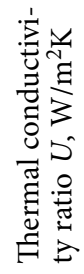 & 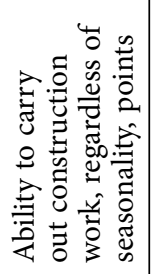 & 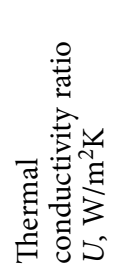 & 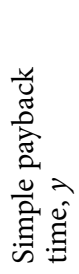 & 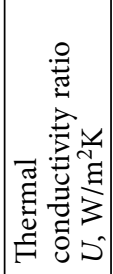 \\
\hline 1 & 2 & 3 & 4 & 5 & 6 & 7 & 8 \\
\hline $\begin{array}{l}\text { Roof } 1 \\
\text { The old roller coating is being removed and the existing } \\
\text { heat-insulation materials are adjusted. } \\
\text { The bottom layer of the } 270 \mathrm{~mm} \text { thick polystyrene foam EPS } \\
80 \text { is paved. } \\
\text { The upper } 30 \mathrm{~mm} \text { thick hard mineral wool ROS } 30 \text { board is } \\
\text { paved and the } 2 \text { layer roller waterproofing coating is fused } \\
\text { (Area } 424 \mathrm{~m}^{2} \text { ) } \\
\text { The parapets are tinned, ventilation ducts insulated }\end{array}$ & 0.12 & 108802 & 25 & 6 & 33.05 & 17 & 520 \\
\hline $\begin{array}{l}\text { Roof } 2 \\
\text { The old roller coating is being removed and the existing } \\
\text { heat-insulation materials are adjusted } \\
\text { The bottom layer of the } 300 \mathrm{~mm} \text { thick polystyrene foam EPS } \\
80 \text { is paved } \\
\text { The upper } 30 \mathrm{~mm} \text { thick hard mineral wool ROS } 30 \text { board is } \\
\text { paved and the } 2 \text { layer roller waterproofing coating is fused } \\
\text { (Area } 424 \mathrm{~m}^{2} \text { ) } \\
\text { The parapets are tinned, ventilation ducts insulated }\end{array}$ & 0.11 & 113971 & 25 & 5 & 33.3 & 17 & 540 \\
\hline
\end{tabular}


End of Table 3

\begin{tabular}{|c|c|c|c|c|c|c|c|}
\hline 1 & 2 & 3 & 4 & 5 & 6 & 7 & 8 \\
\hline $\begin{array}{l}\text { Roof } 3 \\
\text { The old roller coating is being removed and the existing } \\
\text { heat-insulation materials are adjusted } \\
\text { The bottom layer of the } 340 \mathrm{~mm} \text { thick mineral foam ROS } \\
30 \text { is paved } \\
\text { The upper } 30 \mathrm{~mm} \text { thick hard mineral wool ROS } 50 \text { board is } \\
\text { paved and the } 2 \text { layer roller waterproofing coating is fused } \\
\text { (Area } 424 \mathrm{~m}^{2} \text { ) } \\
\text { The parapets are tinned, ventilation ducts insulated }\end{array}$ & 0.10 & 119193 & 25 & 4 & 33.54 & 22 & 590 \\
\hline $\begin{array}{l}\text { Roof } 4 \\
\text { The old roller coating is being removed and the existing } \\
\text { heat-insulation materials are adjusted } \\
\text { The bottom layer of the } 380 \mathrm{~mm} \text { thick polystyrene foam EPS } \\
80 \text { is paved } \\
\text { The upper } 20 \mathrm{~mm} \text { thick hard mineral wool ROS } 30 \text { board is } \\
\text { paved and the } 2 \text { layer roller waterproofing coating is fused } \\
\text { (Area } 424 \mathrm{~m}^{2} \text { ) } \\
\text { The parapets are tinned, ventilation ducts insulated. }\end{array}$ & 0.09 & 123417 & 25 & 6 & 33.78 & 20 & 620 \\
\hline Minimized/maximized & $\min$ & $\min$ & $\max$ & $\max$ & $\max$ & $\min$ & $\max$ \\
\hline Significance, $q$ & 0.136 & 0.260 & 0.132 & 0.0485 & 0.155 & 0.216 & 0.052 \\
\hline
\end{tabular}

variants which have a certain purpose are analysed. Every purpose is shown by indexes. They can be changed according to the objectives we seek.

Constructions are selected in the context of the experts' survey data. Significance of the scale is used to determine the priority. The table, formed in accordance to the completed questionnaires of experts' opinions, is being filled with average values of experts' indicators.

Group assessment may be considered to be quite reliable only when the opinions of surveyed experts are compatible.

Criteria ranks are set in accordance with each survey. The multipurpose decision-making methods TOPSIS, SAW, and COPRAS are applied.

The alternative selection issue, related to the various and contradictory indicators, emerges using the multipurpose decision method (Multiple Attribute Decision Making, MADM).

Subjective and objective analysis has many advantages and disadvantages. Significances, set in subjective point of view, indicate the subjective personal decisions that lead to the rankings of the problem alternatives. Objective decision rankings are determined by mathematical methods based on subjective information.

Technique for options' priority determination is used when the optimal alternative is at the minimum distance from ideal solution and at the greatest distance from worst solution. This method is called Technique for Order Preference by similarity to Ideal Solution (TOPSIS).

Best known Simple Additive Weighting method (SAW) is one of the simplest and most widely applied. Source data - decision matrix and significance sizes. Decision matrix cannot have non-numeric values.

The Synthesis of Multiple Attribute Decisions by three methods (SyMAD-3) is used based on previously described multi-level decision-analysis model. This method is designed to integrate multi-joint decision into a single solution. To increase the reliability of the decision three quantitative measurements based on decision support methods are applied. Following methods are used for the presented algorithm of the method: integrated materiality determination of efficiency and multipurpose solution making, SAW (MacCrimmon 1968), TOPSIS (Hwang, Yoon 1981), and COPRAS (Zavadskas et al. 2004; Kaklauskas et al. 2005) methods.

At the beginning of work decision stage setting is performed, efficiency indicators system for each step of the decision tree $k(k=1,2 \ldots c)$ is formed. Each decision stage decision tabulation, here $m k-k$ is a number of tables of each decision stage. Using these tables decision matrix is formed:

$$
X_{t}=\left[x_{i j}^{t}\right],\left(t=\overline{1, m_{k}} ; i=\overline{1, a_{t}}, j=\overline{1, n_{k}}\right) ;
$$

where: $t$ - decision table number, $a_{t}-t-$ the number 
of alternatives of the certain table, $n_{k}-k$ - the number of efficiency indicators of the certain stage.

Decision matrix $x_{i j}$ is developed in such a shape:

$$
\left[x_{i j}\right]=\begin{gathered}
X_{1} \\
a_{1} \\
a_{2} \\
\ldots \\
a_{m}
\end{gathered}\left[\begin{array}{cccc}
x_{11} & x_{21} & \ldots & x_{1 n} \\
x_{21} & x_{22} & \ldots & x_{2 n} \\
\ldots & \ldots & \ldots & \ldots \\
x_{m 1} & x_{m 2} & \ldots & x_{m n}
\end{array}\right],
$$

where $a_{1}-a_{m}$ - comparative options $(i=1, m)$;

$X_{1}-X_{n}$ - performance indicators $(j=1, n)$;

$x_{11}-x_{m n}-$ performance indicator values.

Purpose of the method is a synthesis of multipurpose solutions using three multipurpose solving methods. Multistage solution tree model depicts the structure of solutions that belong to different tiers analysis.

\begin{tabular}{|c|c|c|c|c|c|c|}
\hline & & & & \multicolumn{3}{|c|}{ Rankings by } \\
\hline $\begin{array}{l}\text { Alter- } \\
\text { native } \\
\text { combi- } \\
\text { nations }\end{array}$ & Plinth & Wall & Roof & $\begin{array}{c}\text { TOP- } \\
\text { SIS }\end{array}$ & SAW & $\begin{array}{c}\text { COP- } \\
\text { RAS }\end{array}$ \\
\hline $\mathrm{B}^{1}$ & plinth 1 & wall 1 & roof 1 & 33 & 34 & 35 \\
\hline $\mathrm{B}^{2}$ & plinth 1 & wall 1 & roof 2 & 27 & 29 & 28 \\
\hline $\mathrm{B}^{3}$ & plinth 1 & wall 1 & roof 3 & 61 & 61 & 61 \\
\hline $\mathrm{B}^{4}$ & plinth 1 & wall 1 & roof 4 & 46 & 48 & 47 \\
\hline $\mathrm{B}^{5}$ & plinth 1 & wall 2 & roof 1 & 28 & 24 & 24 \\
\hline$B^{6}$ & plinth 1 & wall 2 & roof 2 & 24 & 21 & 21 \\
\hline $\mathrm{B}^{38}$ & plinth 3 & wall 2 & roof 2 & 1 & 1 & 1 \\
\hline $\mathrm{B}^{39}$ & plinth 3 & wall 2 & roof 3 & 47 & 37 & 41 \\
\hline$B^{40}$ & plinth 3 & wall 2 & roof 4 & 15 & 8 & 7 \\
\hline $\mathrm{B}^{41}$ & plinth 3 & wall 3 & roof 1 & 5 & 4 & 5 \\
\hline $\mathrm{B}^{42}$ & plinth 3 & wall 3 & roof 2 & 3 & 3 & 3 \\
\hline$B^{43}$ & plinth 3 & wall 3 & roof 3 & 49 & 43 & 44 \\
\hline $\mathrm{B}^{44}$ & plinth 3 & wall 3 & roof 4 & 20 & 12 & 13 \\
\hline$B^{45}$ & plinth 3 & wall 4 & roof 1 & 16 & 18 & 14 \\
\hline$B^{46}$ & plinth 3 & wall 4 & roof 2 & 12 & 13 & 10 \\
\hline $\mathrm{B}^{47}$ & plinth 3 & wall 4 & roof 3 & 52 & 54 & 53 \\
\hline $\mathrm{B}^{48}$ & plinth 3 & wall 4 & roof 4 & 34 & 33 & 32 \\
\hline$B^{49}$ & plinth 4 & wall 1 & roof 1 & 13 & 20 & 20 \\
\hline $\mathrm{B}^{50}$ & plinth 4 & wall 1 & roof 2 & 10 & 16 & 15 \\
\hline$B^{51}$ & plinth 4 & wall 1 & roof 3 & 57 & 56 & 56 \\
\hline
\end{tabular}

Table 4. Table of alternative combinations

\subsection{The addressing of the Vaidotai st. EC checkpoint modernization}

Multilevel decision model is being established, taking into account the insulation options of plinth, walls, and roof. Four plinth, four walls and four roof insulation options are analyzed (Table 4).

Decision on which plinth, wall and roof insulation method would be most rational, assessing them in complex,

has to be made; decision tree model is formed by the evaluation of the complex alternative combinations to be carried out (see Fig. 8, which shows the rational alternative combination).

\subsection{Decision search tree diagram of the insulation version}

Equal set of modernization indicators is formed for each stage of modernization. Each plinth, wall and roof alternative was assessed according to 7 indicators of modernization.

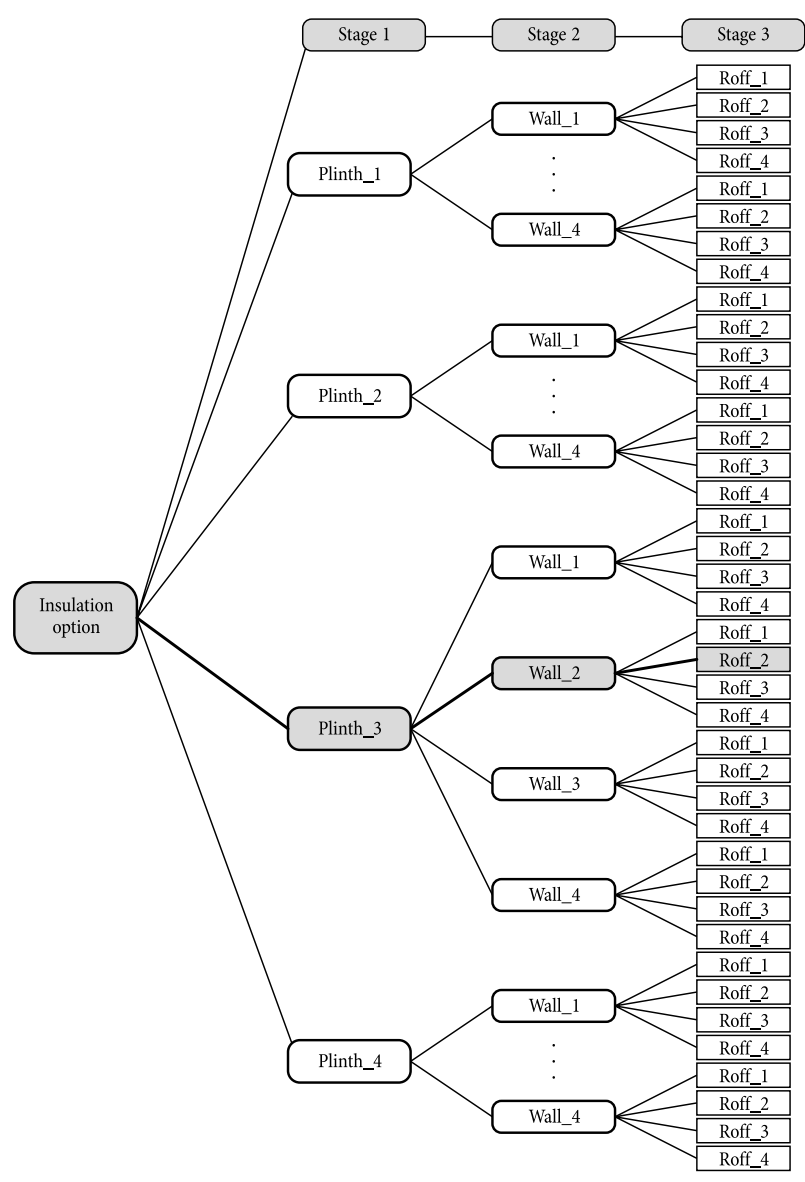

Fig. 8. Alternative combinations decision tree 


\section{BIM technology}

Benefits identified during the construction phase include less rework, reduction in requests for information and change orders, customer satisfaction through visualization, improved productivity in phasing and scheduling, faster and more effective construction management with easier information exchange, accurate cost estimation, and visualizing safety analysis (Hardin 2009; Elbeltagi, Dawood 2010; Eastman et al. 2011; Azhar 2011; Hartmann et al. 2012; Migilinskas et al. 2013). During operation phase this technology includes control of facilities management progress, integrated life-cycle data, rapid and accurate information of updating and changing activities, and more effective facility management with easier information exchange (Popov et al. 2010; Eastman et al. 2011; Hardin 2009; Klein et al. 2012).

This system gives ability to model changes in the structure of the building, re-design building engineering equipment, to renew the information which then satisfies the exploitation requirements, monitor the current status of the building and take timely action for the restoration, competently operate existing facilities. Both technologically and economically BIM is an additional model for a project's engineering information database, storing all the architectural designs with geometric information and the corresponding technical information for all the works (Ding et al. 2012).

BIM construction standardization contains not only geometry of walls, columns, beams, doors, windows, and other building components, but also contains specific attributes for each object, such as material type, material properties and vendor.

BIM methodology can be used to make project simulations like Virtual Project Development (VPD). This helps to evaluate an effectiveness of Project Management implementation in the 5D environment (Popov et al. 2010). Updating the as-built schedule during the construction phase is generally recognized as the most critical strategy for successful Schedule (Tserng et al. 2014) and cash flow management.

With selected types of structures the design works task can be formulated.

The benefits that people can gain from BIM are based on the energy analysis which offers better data and possibility to reuse the existing data more efficiently. It also suggests the ability to use dynamic energy simulation instead of static methods and use the whole building spatial simulation instead of zone based approach. Although, the major benefit that BIM offers is that it gives the possibility to get the approval of energy performance in the whole building life cycle. From the project experiences it is obvious that BIM also is needed to revise management by comparing different revisions, making visualisations of thermal performances and getting architect model validations so as to analyse their development.

\section{Conclusions}

- The examination and comprehensive analysis of the object found that: relative humidity of the air is low, which in accordance with HN42: 2012 does not meet public indoor comfort conditions requirements and increases the costs of building heating. The high heat loss through the walls, roof, plinth, and other constructions is detected, high heating costs, too low room temperature, too low relative humidity, poor ventilation, and other problems are indicated.

- Significances of selected alternative were determined by the pair comparison method interviewing 12 experts. The results were systematized and used for further calculations.

- Studies and calculations were made using the methods of SAW, TOPSIS, COPRAS and SyMAD-3. The best combination of building modernization alternatives were set and the rest were aligned in accordance of their beneficence.

- The best combination of the alternatives was set in accordance with the calculations made: Plinth 3 Wall 2 - Roof -2.

- It is proposed to use the best combination of the alternatives based on the calculations as in that way the best thermal results, lowest cost, and most cost savings for heating during the cold season can be achieved.

- BIM model which describes the components is prepared for building modernization.

- BIM technology allows to use simulation of visualization and energy calculation in building model.

\section{References}

Azhar, S. 2011. Building Information Modeling (BIM): trends, benefits, risks, and challenges for the AEC industry, Leadership and Management in Engineering 11(3): 241-252. http:// dx.doi.org/10.1061/(asce)lm.1943-5630.0000127

Balaras, C. A.; Droutsa, K.; Dascalaki, E.; Kontoyiannidis, S. 2005. Heating energy consumption and resulting environ- 
mental impact of European apartment buildings, Energy and Buildings 37(5): 429-442.

http://dx.doi.org/10.1016/j.enbuild.2004.08.003

Bayir, E.; Seker, N. N. C.; Karaoglu, M. 2013. The analysis on examples of energy efficiency in passive houses in terms of interior comfort, in 2013 International Conference on Renewable Energy Research and Applications (ICRERA), 20-23 October 2013, Madrid, Spain, 984-989.

http://dx.doi.org/10.1109/icrera.2013.6749895

Ding, L. Y.; Zhou, Y.; Luo, H. B.; Wu, X. G. 2012. Using nD technology to develop an integrated construction management system for city rail transit construction, Automation in Construction 21(7): 64-73.

http://dx.doi.org/10.1016/j.autcon.2011.05.013

Elbeltagi, E.; Dawood, M. 2011. Integrated visualized time control system for repetitive construction projects, Automation in Construction 20(7): 940-953.

http://dx.doi.org/10.1016/j.autcon.2011.03.012

Eastman, C.; Teicholz, P.; Sacks, R.; Liston, K. 2011. BIM handbook: a guide to building information modeling for owners, managers, designers, engineers and contractors. Hoboken: Wiley.

Hardin, B. 2009. BIM and construction management: proven tools, methods, and workflows. New Jersey: John Wiley and Sons.

Harris, J. 2013. Integration of BIM and business strategy. Evanston: Northwestern University.

Hartmann, T.; Meerveld, H. V.; Vossebeld, N.; Adriaanse, A. 2012. Aligning building information model tools and construction management methods, Automation in Construction 22: 605-613. http://dx.doi.org/10.1016/j.autcon.2011.12.011

Heesom, D.; Mahdjoubi, L. 2004. Trends of 4D CAD applications for construction planning, Construction Management and Economics 22(2): 171-182.

http://dx.doi.org/10.1080/0144619042000201376

HN 42:2009. Gyvenamųjų ir visuomeninių pastatų patalpų mikroklimatas [Residential and public buildings, indoor climate]. Valstybes žinios, 2005, Nr. 151-5568. Approved by the Order No. D1-624 of the Minister of the Environment of the Republic of Lithuania, 20 December 2005.

Hwang, C. L.; Yoon K. 1981. Multiple attribute decision making - methods and applications. A state of the art survey. Berlin, Heidelberg, New York: Springer Verlag. 250 p.

Jarrar, O. M.; Al-Zoabi, A. Y. 2008. The applicability of sustainable city paradigm to the city of Jerusalem: criteria and indicators of efficiency, Building and Environment 43(4): 550-557. http://dx.doi.org/10.1016/j.buildenv.2007.01.025

Kaklauskas, A.; Zavadskas, E. K.; Raslanas, S. 2005. Multivariant design and multiple criteria analysis of building refurbishments, Energy and Buildings 37(4): 361-372. http://dx.doi. org/10.1016/j.enbuild.2004.07.005

Klein, L.; Li, N.; Becerik-Gerber, B. 2012. Imaged-based verification of as-built documentation of operational buildings, Automation in Construction 21(1): 161-171. http://dx.doi.org/10.1016/j.autcon.2011.05.023

LST EN ISO 7730:2006. Ergonomics of the thermal environment - Analytical determination and interpretation of thermal comfort using calculation of the PMV and PPD indices and local thermal comfort criteria (ISO 7730:2005). 2006-02-28, TK 64 Ergonomika.
MacCrimmon, K. R. 1968. Decision marking among multipleattribute alternatives: a survey and consolidated approach. RAND Memorandum, RM-4823-ARPA.

Migilinskas, D.; Popov, V.; Juocevicius, V.; Ustinovichius, L. 2013. The benefits, obstacles and problems of practical BIM implementation, Procedia Engineering 57: 767-774. http://dx.doi.org/10.1016/j.proeng.2013.04.097

Popov, V.; Juocevicius, V.; Migilinskas, D.; Ustinovichius, L.; Mikalauskas, S. 2010. The use of a virtual building design and construction model for developing an effective project concept in 5D environment, Automation in Construction 19: 357-367. http://dx.doi.org/10.1016/j.autcon.2009.12.005

San-José Lombera, J.-T.; Cuadrado Rojo, J. 2014. Industrial building design stage based on a system approach to their environmental sustainability, Construction and Building $\mathrm{Ma}$ terials 24: 438-447.

http://dx.doi.org/10.1016/j.conbuildmat.2009.10.019

STR 2:02:02:2004. Visuomeninès paskirties statiniai [Public buildings]. Valstybės Žinios, 2004, Nr. 54-1851. Approved by the Order No. D1-91 of the Minister of the Environment of the Republic of Lithuania, 27 February 2004.

STR 2.01.09:2012. Pastatu energinis naudingumas. Energinio naudingumo sertifikavimas [Energy performance of buildings. Energy performance certification]. Valstybès žinios, 2005, Nr. 151-5568. Approved by the Order No. D1-624 of the Minister of the Environment of the Republic of Lithuania, 20 December 2005.

STR 1.01.09:2003 Statinių klasifikavimas pagal jų naudojimo paskirti [Building classification according to their usage]. Valstybès Žinios, 2003, Nr. 58-2611. Approved by the Order No. 289 of the Minister of the Environment of the Republic of Lithuania, 11 June 2003.

Talapov, V. V. 2011. Osnovy BIM: vvedenie v informacionnoe modelirovanie zdanij. Moskva: DMK PRESS.

Taylor, J. E.; Bernstein, P. G. 2009. Paradigm trajectories of building information modeling practice in project networks, Journal of Management in Engineering 25(2): 69-76. http://dx.doi.org/10.1061/(asce)0742-597x(2009)25:2(69)

Tserng, H.-P.; Ho, Sh.-P.; Jan, Sh.-H. 2014. Developing BIMassisted as-built schedule management system for general contractors, Journal of Civil Engineering and Management 20(1): 47-58.

http://dx.doi.org/10.3846/13923730.2013.851112

Volvačiovas, R.; Turskis, Z.; Ignatavičius, Č.; Ustinovičius, L.; Ruzgys, A. 2012. Considering the issue of renovating public buildings with reference to in-kind investigations into wall heat transfer coefficients, Journal of Engineering Structures and Technologies 5(2): 82-91. http://dx.doi.org/10.3846/20 29882x.2013.811783

Wang, N.; Chang, Y.-C.; Nunn, C. 2010. Lifecycle assessment for sustainable design options of a commercial building in Shanghai, Building and Environment 45(6): 1415-1421. http://dx.doi.org/10.1016/j.buildenv.2009.12.004

Wong, K.; Fan, Q. 2012. Building information modelling (BIM) for sustainable building design, Facilities 31(3/4): 138-157. http://dx.doi.org/10.1016/j.autcon.2004.04.003 http:// dx.doi.org/10.1108/02632771311299412

Zavadskas, E. K.; Kaklauskas, A.; Banaitis, A.; Kvederyte, N. 2004. Housing credit access model: The case for Lithuania, European Journal of Operational Research 155(2): 335-352. http://dx.doi.org/10.1016/s0377-2217(03)00091-2 
Romas RASIULIS. PhD student at Department of construction technology and Management, Vilnius Gediminas Technical University. Research interests: multicriteria evaluation and automated programming of technological decision in construction, construction technology and management, decision-making, energy efficiency, renovation.

Leonas USTINOVICHIUS. Professor Dr habil at Vilnius Gediminas Technical University and Bialystok University of Technology. Education: Industrial and Civil Engineering, Construction Engineer, visi (VGTU), 1982; candidate of Technical Sciences Dnepropetrovsk ISI, 1989; Associate Professor, VGTU, 1993; Doctor of Technical Sciences, VGTU, 1994; Doctor habilitatus, VGTU, 2003; Professor, VGTU, 2007. Research interests: multicriteria evaluation and automated programming of technological decision in construction, operational research methods, technology of construction process, quantitative and qualitative decision making methods, organization and performance of construction firm.

Jovita CEPURNAITE. PhD student at Department of construction technology and Management, Vilnius Gediminas Technical University. Research interests: automated programming of technological decision in construction, construction technology and management, decision-making, energy efficiency, renovation.

Darius MIGILINSKAS. Associate professor at Department of Construction Technology and Management, Vilnius Gediminas Technical University. Doctor of Technological Sciences, Civil engineering 02T) in VGTU, 2010. Research interests: new technologies and management of construction works; plm and bim modelling in civil engineering; uncertainty and risk management; game theory in construction's decision making. Over 40 scientific articles in international scientific journals and international conferences.

Arvydas VIRBICKAS. Master's degree in construction technology and management, Vilnius Gediminas Technical University. Research interests: automated programming of technological decision in construction, construction technology and management, energy efficiency and construction research. 